\title{
The Therapeutic Function of Testamentary Formality
}

\author{
Mark Glover ${ }^{*}$
}

\section{INTRODUCTION}

Using a therapeutic jurisprudential framework of estate planning as its analytical foundation, ${ }^{1}$ this Article examines the role of testamentary formality in the estate planning process. This analysis demonstrates that formal will-execution requirements bolster the overall therapeutic potential of estate planning, ${ }^{2}$ or, put differently, it suggests that testamentary formality serves a therapeutic function. This therapeutic function stems from the unique relationship between will formalities and the therapeutic potential of the estate planning process. Because legal scholars and law reformers have overlooked this connection and therefore have failed to recognize testamentary formality's therapeutic qualities, this Article provides a fresh perspective of the role of formality in the will-execution process and sheds new light on the merits of various reforms of the law of wills.

Therapeutic jurisprudential analysis, which is founded upon "the insight that the law itself can be seen to function as a kind of therapist or therapeutic agent," ${ }^{3}$ reveals that estate planning has therapeutic and antitherapeutic qualities. These qualities affect the psychological wellbeing of those who prepare estate plans and implement those plans

* Teaching Fellow and Assistant Professor of Professional Practice, Louisiana State University, Paul M. Hebert Law Center. LL.M. 2011, Harvard Law School; J.D. 2008, magna cum laude, Boston University School of Law. Special thanks to Professor Robert Sitkoff, who provided guidance throughout the course of this project.

1. See generally Mark Glover, A Therapeutic Jurisprudential Framework of Estate Planning, 35 SEATtLe U. L. REV. 427, 433-61 (2012) (detailing the components of the jurisprudential framework); see also David Wexler, Therapeutic Jurisprudence, 20 TOURO L. REV. 353, 355-56 (2004) [hereinafter Wexler, Therapeutic Jurisprudence] (describing the origins of therapeutic jurisprudence); David Wexler, Therapeutic Jurisprudence: An Overview, 17 T.M. COOLEY L. REV. 125, 125 (2000) [hereinafter Wexler, Therapeutic Jurisprudence Overview] (noting that therapeutic jurisprudential issues "have not received very much attention in the law until now").

2. See infra Part III.A.

3. Bruce J. Winick, The Jurisprudence of Therapeutic Jurisprudence, 3 Psychol. PUB. POL'Y \& L. 184, 185 (1997). 
through the execution of wills and other estate planning documents. ${ }^{4}$ As an integral part of this process, ${ }^{5}$ will formalities-such as the requirements that wills be written, signed by the testator, and attested by at least two witnesses ${ }^{6}$ - frequently interact with and influence the therapeutic aspects of estate planning. ${ }^{7}$ Because of this link between testamentary formality and the psychological consequences of preparing for the final disposition of one's property, will formalities have the capacity to either promote or diminish the overall therapeutic potential of the estate planning process.

Although therapeutic jurisprudence reveals that testamentary formality can produce both therapeutic and antitherapeutic effects, ${ }^{8}$ this Article argues that will formalities ultimately achieve a net therapeutic outcome. The recognition of such a therapeutic function represents the first step of a therapeutic jurisprudential analysis, a task that entails the identification of the law's positive and negative psychological consequences. ${ }^{9}$ The completion of this first step provides new insights into the benefits of testamentary formality. ${ }^{10}$ It also suggests that losing these benefits is a potential unforeseen cost of two recent developments in the law of wills that have diminished the role of formality in the estate planning process and that, therefore, threaten to undermine formality's therapeutic function.

First, proponents of reform have pushed for a reduction of testamentary formality, which would eliminate or replace some of the traditional formal requirements of will execution. ${ }^{11}$ Second, the law reform movement has argued for the relaxation of the formalism that has long required strict literal compliance with the prescribed formalities. This reform would allow probate courts to validate some wills despite noncompliance with the prescribed formalities. ${ }^{12}$ The second step of

4. See Glover, supra note 1, at 433-61.

5. See Kent D. Schenkel, Testamentary Fragmentation and the Diminishing Role of the Will: An Argument for Revival, 41 CREIGHTON L. REV. 155, 160 (2008).

6. See Jesse DuKeminier, Robert H. SitKoff \& JAMES Lindgren, Wills, TRUSTS, AND ESTATES 226 (8th ed. 2009) (explaining that "these basic requirements for execution of wills vary considerably in detail from state to state.”).

7. See Glover, supra note 1, at 465-67 (discussing this phenomenon in the context of the reduced formal requirements of military wills).

8. See id. at 433-65.

9. See Wexler, Therapeutic Jurisprudence Overview, supra note 1, at 125-26.

10. See Glover, supra note 1, at 443-61 (illustrating this first step in the context of estate planning).

11. See infra Part IV.A.

12. See infra Part IV.B. 
therapeutic jurisprudence is to identify ways to maximize the law's therapeutic aspects and minimize its negative psychological consequences. ${ }^{13}$ As such, a therapeutic jurisprudential analysis of will formalities requires an examination of these proposed reforms to determine which would maximize the law's overall therapeutic potential. Using this therapeutic jurisprudential framework, this Article reexamines the law reform developments that threaten testamentary formality's therapeutic potential and argues that therapeutic considerations should be included in the debate regarding the proper role of testamentary formality.

Ultimately, the application of therapeutic jurisprudence to the study of testamentary formality affirms calls for certain reforms of the law of wills, such as the reduction of ancillary testamentary formality ${ }^{14}$ and the authorization of notarized wills. ${ }^{15}$ The analysis also raises doubts regarding the merits of another proposed reform, namely the elimination of the attestation requirement. ${ }^{16}$ Perhaps most importantly, however, therapeutic jurisprudence reasserts the need to relax the formalism that mandates strict literal compliance with the formalities of will execution. ${ }^{17}$ Despite widespread support within the legal academy, change in this area has been slow moving. ${ }^{18}$ In hopes of spurring progress in this reform effort, this Article's therapeutic jurisprudential analysis uniquely demonstrates the harshness of the rule of strict compliance and further bolsters the arguments in favor of reform. ${ }^{19}$

This Article proceeds in three parts. Part II provides an overview of therapeutic jurisprudence and introduces the therapeutic jurisprudential framework of estate planning. Part III presents the first step of therapeutic jurisprudential analysis and identifies the therapeutic function of testamentary formality. Finally, by analyzing the implications of testamentary formality's therapeutic function, Part IV undertakes the second step of a therapeutic jurisprudential analysis and argues that formality's ther-

13. See Jason Schultz, Can Women Judges Help Make Civil Sexual Assault Trials More Therapeutic?, 16 WIs. WOMEN's L.J. 53, 54 (2001); Wexler, Therapeutic Jurisprudence Overview, supra note 1 , at 125 .

14. See infra Part IV.A.1.

15. See infra Part IV.A.3.

16. See infra Part IV.A.2.

17. See infra Part IV.B.

18. See Stephanie Lester, Admitting Defective Wills to Probate, Twenty Years Later: New Evidence for the Adoption of the Harmless Error Rule, 42 REAL PROP. PROB. \& TR. J. 577, 601-602 (2007) (explaining that only eight states have implemented a harmless error rule in the U.S., and of those states, only a few have applied the rule).

19. See infra Part IV.B. 
apeutic benefits should be included in the discussion regarding testamentary formality's proper role in the estate planning process.

\section{THERAPEUTIC JURISPRUDENCE AND THE LAW OF SUCCESSION}

Over the past twenty years, ${ }^{20}$ therapeutic jurisprudence has emerged as an analytical tool that provides fresh perspectives of the formerly ignored psychological and emotional consequences of the law. ${ }^{21}$ As Professor David Wexler, a prominent scholar in the field, explains, therapeutic jurisprudence "focuses on the law's impact on emotional life and on psychological well-being," and "focuses our attention on this previously underappreciated aspect, humanizing the law and concerning itself with the human, emotional, [and] psychological side[s] of law and the legal

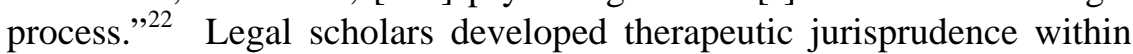
the field of mental health law, ${ }^{23}$ and, since its emergence, therapeutic jurisprudential analysis has spread to numerous other areas. ${ }^{24}$ Indeed, proponents continue to broaden the scope of therapeutic jurisprudence and argue for its expansion to all areas of law. ${ }^{25}$

\section{A. Therapeutic Jurisprudential Analysis}

A therapeutic jurisprudential analysis consists of two steps. First, therapeutic jurisprudence entails identifying the positive and negative

20. See Marilyn McMahon \& David Wexler, Therapeutic Jurisprudence: Developments and Applications in Australia and New Zealand, in THERAPEUTIC JURISPRUDENCE 1, 1 (Marilyn McMahon \& David Wexler eds., 2003); Winick, supra note 3, at 184.

21. Wexler, Therapeutic Jurisprudence, supra note 1, at 356 ("The law's influence on emotional life and psychological well-being has traditionally been ignored by the law or regarded as something apart from the law and its concern. But therapeutic jurisprudence as an academic discipline started focusing on different kinds of legal arrangements and therapeutic outcomes.”).

22. Wexler, Therapeutic Jurisprudence Overview, supra note 1, at 125; see also Winick, supra note 3, at 185 ("Therapeutic jurisprudence is the study of the role of the law as a therapeutic agent.”).

23. McMahon \& Wexler, supra note 20, at 1.

24. See Susan Daicoff, Law as a Healing Profession: The "Comprehensive Law Movement," 6 PEPP. DisP. RESOL. L.J. 1, 11 (2006) (explaining that therapeutic jurisprudence has "spread into many other areas," such as "sentencing and probation agreements, workers' compensation law, sexual orientation law, disability law, fault-based tort compensation schemes, domestic violence, crime victims, mandatory child abuse reporting, contract law, and family law” (footnotes omitted)).

25. See, e.g., Gregory Baker, Rediscovering Therapeutic Jurisprudence in Overlooked Areas of the Law-How Exposing Its Presence in the Environmental Justice Movement Can Legitimize the Paradigm and Make the Case for Its Inclusion into All Aspects of Legal Education and the Practice of Law, 9 FLA. COASTAL L. REV. 215, 218 (2008). 
psychological consequences of a particular aspect of the law. ${ }^{26}$ These positive and negative psychological consequences are labeled therapeutic and antitherapeutic. ${ }^{27}$ Second, the framework developed in the first step of the analysis is used to identify ways that the law can be shaped to maximize its overall therapeutic potential. ${ }^{28}$ The analysis achieves this goal by analyzing how potential reforms would either bolster the law's positive psychological qualities or diminish its antitherapeutic consequences. $^{29}$ In this regard, therapeutic jurisprudence seeks to maximize the therapeutic potential of not only substantive laws, but also procedural rules and the roles of those who participate in the legal process. ${ }^{30}$

Although a therapeutic jurisprudential analysis seeks to maximize the law's overall therapeutic potential, therapeutic jurisprudence does not demand that the most therapeutic outcome prevail. ${ }^{31}$ Therapeutic jurisprudence merely suggests that therapeutic issues should be evaluated alongside other policy considerations. ${ }^{32}$ As Wexler explains, "therapeutic jurisprudence does not itself suggest that therapeutic goals should trump other ones .... It is simply a way of looking at the law in a richer way, and then bringing to the table some of these areas and issues that previously have gone unnoticed.”33 In sum, therapeutic jurisprudence encourages the inclusion of therapeutic considerations in the cost-benefit analysis of the law and proposes that, all else being equal, the law should be shaped to maximize its therapeutic potential.

\section{B. The Therapeutic Jurisprudence of Estate Planning}

The estate planning and probate processes are emotionally charged and raise a number of psychological issues. ${ }^{34}$ Therapeutic jurisprudence

\footnotetext{
26. See Wexler, Therapeutic Jurisprudence Overview, supra note 1, at 125-26.

27. Id.

28. See Schultz, supra note 13 , at 54

29. Winick, supra note 3, at 185.

30. See Wexler, Therapeutic Jurisprudence Overview, supra note 1, at 126.

31. See Christopher Slobogin, Therapeutic Jurisprudence: Five Dilemmas to Ponder, 1 PsYCHOL. PUB. POL'Y \& L. 193, 211-12 (1995) (“[T]he goal of therapeutic jurisprudence is to pinpoint the therapeutic impact of legal rules, not to require that therapeutic values trump other values.”); see, e.g., David B. Wexler, New Directions in Therapeutic Jurisprudence: Breaking the Bounds of Conventional Mental Health Law Scholarship, 10 N.Y.L SCH. J. HUM. RTS. 759, 762 (1993).

32. See Schultz, supra note 13, at 54 (listing other factors that could be considered alongside therapeutic considerations, such as "constitutionality, individual autonomy, integrity of the factfinding process, and community safety.”).

33. Wexler, Therapeutic Jurisprudence Overview, supra note 1, at 125.

34. See Patricia Monroe Wisnom, Note, Probate Law and Mediation: A Therapeutic Perspective, 37 ARIZ. L. REV. 1345, 1354 (1995).
} 
is therefore an especially insightful analytical tool with respect to the law of succession. ${ }^{35}$ Despite the intuitive connection between therapeutic jurisprudence and the law of succession, legal scholars generally have failed to broadly apply the therapeutic jurisprudential framework in the estate planning and probate contexts. ${ }^{36}$ Recognizing this analytical opportunity, recent scholarship urges the widespread application of therapeutic jurisprudence to the law of succession. ${ }^{37}$ Specifically, by examining the therapeutic and antitherapeutic qualities of estate planning, such scholarship develops a therapeutic jurisprudential framework of the estate planning process, which can be used to evaluate the therapeutic consequences of a broad array of estate planning issues. ${ }^{38}$

Because wills - and therefore will formalities - are inherent aspects of the estate planning process, ${ }^{39}$ the therapeutic jurisprudential analysis of testamentary formality must take place within the larger framework of estate planning. When examined within this context, therapeutic jurisprudence reveals that will formalities interact with the therapeutic qualities of estate planning and affect the overall therapeutic potential of the estate planning process. However, before undertaking the analysis of how formal will-execution requirements influence the therapeutic aspects of the estate planning process, the larger therapeutic jurisprudential framework of estate planning must be established. ${ }^{40}$

\section{Antitherapeutic Aspects of Estate Planning}

A therapeutic jurisprudential analysis of estate planning reveals that certain aspects of the estate planning process can negatively affect the testator's psychological well-being. The first and perhaps most obvious of these antitherapeutic qualities is the death anxiety that the testator can experience as a result of acknowledging her own mortality. ${ }^{41}$ When preparing and implementing an estate plan, the testator must necessarily

35. See Glover, supra note 1, at 432-33.

36. See id. Some examples of the application of therapeutic jurisprudence to the law of succession do exist. See, e.g., Pamela R. Champine, A Sanist Will?, 46 N.Y.L. SCH. L. REV. 547, 560-62 (2002-2003) (providing a therapeutic jurisprudential analysis of testamentary capacity); Dara Greene, Note \& Comment, Antemortem Probate: A Mediation Model, 14 OHIO ST. J. ON DISP. RESOL. 663, 679-80 (1999) (exploring the therapeutic ramifications of mediation); Wisnom, supra note 34, at 1354 (analyzing the role of the personal representative within the probate process).

37. See generally Glover, supra note 1.

38. Id. at 467-70.

39. See supra notes 5-7 and accompanying text.

40. See Glover, supra note 1, at 433-61.

41. Id. at 434-38. 
confront the possibility of death. ${ }^{42}$ Indeed, the sole purpose of estate planning is to prepare for death, and because acknowledging one's mortality is typically unpleasant and potentially severely disturbing, ${ }^{43}$ the estate planning process can produce death anxiety and other negative psychological effects. ${ }^{44}$ These antitherapeutic consequences may dissuade the testator from completing her estate plan and may impair the testator's decision-making capabilities. ${ }^{45}$

A second antitherapeutic aspect of the estate planning process is the possibility of an estate dispute, ${ }^{46}$ as those who prepare estate plans often worry that their families will argue over their wealth once they are gone. ${ }^{47}$ The primary reason that the potential for estate disputes can cause anxiety for those preparing estate plans is that estate litigation generally produces familial conflict. ${ }^{48}$ This intrafamily conflict can devastate familial bonds, sometimes irreparably damaging previously amicable families. ${ }^{49}$ Familial conflict is not the only consequence of an estate dispute that may worry testators. For example, probate litigation frequently delves into intensely personal issues, such as the testator's mental capacity, complicated family dynamics, and economic and financial matters. ${ }^{50}$ Such information can be embarrassing when displayed in a public forum

42. Id. at 434 .

43. See Charles I. Nelson \& Jeanne M. Starck, Formalities and Formalism: A Critical Look at the Execution of Wills, 6 PEPP. L. REV. 331, 348 (1979) (explaining that "facing the reality of death and its attendant consequences is one of the most difficult responsibilities in life.”); Thomas L. Shaffer, The “Estate Planning” Counselor and Values Destroyed by Death, 55 IowA L. REV. 376, 377 (1969) (“[D]eath is an unpleasant fact to modern man.”).

44. See Glover, supra note 1 , at 434-35.

45. See id. at 435-38 (discussing the extent to which people with death anxiety avoid activities that require considerations of death).

46. Id. at 438-41.

47. See Jennifer Harper, Splitting Heirs Over Wealth: But Children Usually Inherit Most of It, WASH. TIMES, June 28, 2006, at A1 (reporting that 18\% of affluent Americans fear that their families will fight over their estates).

48. See Susan N. Gary, Mediation and the Elderly: Using Mediation to Resolve Probate Disputes Over Guardianship and Inheritance, 32 WAKE FOREST L. REV. 397, 397 (1997) ("Persons planning the transfer of property after death . . . view family harmony as a tangential, but important goal.”); Mary F. Radford, An Introduction to the Uses of Mediation and Other Forms of Dispute Resolution in Probate, Trust, and Guardianship Matters, 34 REAL ProP. ProB. \& TR. J. 601, 63738 (2000) ("Many, if not most, cases arising in probate, trust, and guardianship involve families whose relationships could be irreparably shattered by bitter and prolonged litigation.”).

49. See Gary, supra note 48, at 397; Radford, supra note 48, at 637-38; Yolanda Vorys, Note, The Best of Both Worlds: The Use of Med-Arb for Resolving Will Disputes, 22 OHIO ST. J. DISP. RESOL. 871, 874-75 (2007).

50. See Rudd v. Searles, 160 N.E. 882, 886 (Mass. 1928) (“Contests over the allowance of wills frequently, if not invariably, result in minute examination into the habits, manners, beliefs, conduct, idiosyncrasies, and all the essentially private and personal affairs of the testator .....”). 
and can exacerbate preexisting familial tension. ${ }^{51}$ Because the testator may fear public airing of her family's "dirty laundry," ${ }^{\text {,2 }}$ the potential for estate disputes is one antitherapeutic consequence of the estate planning process.

The final antitherapeutic aspect of estate planning is the testator's fear of probate. ${ }^{53}$ Probate is the process by which the testator's debts are paid and property is distributed to the estate beneficiaries. ${ }^{54}$ Those who prepare estate plans often fear this process for several reasons. First, probate can be costly. ${ }^{55}$ Numerous expenses arise during the probate process, such as attorney's fees and court costs, ${ }^{56}$ and testators often fear that such costs will substantially deplete their estates. ${ }^{57}$ Second, the probate process can be protracted. ${ }^{58}$ Probate is judicially supervised, which can slow the administration of the decedent's estate. ${ }^{59}$ Consequently, testators sometimes fear probate because they do not want their friends and family members to deal with the stress of the probate process during a time when they are still grieving the loss of a loved one. ${ }^{60}$ Finally, testators sometimes fear probate because the process can be intrusive. ${ }^{61}$ As discussed previously, if an estate dispute arises, deeply private and po-

51. See Martin D. Begleiter, Anti-Contest Clauses: When You Care Enough to Send the Final Threat, 26 ARIZ. ST. L.J. 629, 636 (1994) (explaining that "the publicity surrounding a will contest" is characterized by "ridicule, contempt, and criticism"); Lela P. Love \& Stewart E. Sterk, Leaving More Than Money: Mediation Clauses in Estate Planning Documents, 65 WASH. \& LEE L. REV. 539, 567 (2008) ("A testator whose dispositions depart from social norms may fear a contest because the trial will expose his or her personal life, and that of his family, to public humiliation or ridicule.”).

52. See Begleiter, supra note 51, at 636-39 (describing the scrutiny under which a testator's life is examined during a will contest under the heading of "Family Antagonism and the Airing of Dirty Linen in Public"); Love \& Sterk, supra note 51, at 567 (explaining that "[a] testator ... may fear a [will] contest because ... [ [of] the prospect that the family's dirty laundry will be aired in public.”).

53. Glover, supra note 1, at 441-43.

54. See DUKEMINIER ET AL., supra note 6, at 39.

55. See John H. Martin, Reconfiguring Estate Settlement, 94 MinN. L. REV. 42, 50 (2009).

56. See DUKEMINIER ET AL., supra note 6, at 45 ("Much is heard about the excessive cost of probate—or, as some have put it, the high cost of dying.").

57. See Martin, supra note 55, at 50.

58. See id. at 48.

59. See William M. McGovern, Sheldon F. Kurtz \& David M. ENGLish, Wills, Trusts AND ESTATES 630 (4th ed. 2010) ("[A]dministration of an estate typically lasts for many months or even years.").

60. See Glover, supra note 1, at 442 ("[T]estators realize that their families will be coping with their deaths during the probate process ....").

61. See Frances H. Foster, Privacy and the Elusive Quest for Uniformity in the Law of Trusts, 38 ARIZ. ST. L.J. 713, 722 (2006) ("Once a will is filed for probate, it becomes public record for all the world to see."). 
tentially embarrassing issues may be publicly examined, which can produce anxiety in those who undertake the estate planning process. ${ }^{62}$ The antitherapeutic aspects of the therapeutic jurisprudential framework of estate planning therefore include the testator's fear of probate, the possibility of estate disputes and familial conflict, and the testator's confrontation with death.

\section{Therapeutic Aspects of Estate Planning}

In addition to these antitherapeutic aspects, the therapeutic jurisprudential framework of estate planning has a number of therapeutic components that positively affect the psychological well-being of the testator. ${ }^{63}$ For example, the testator can experience positive psychological consequences from the broad liberty to craft an estate plan that best meets her preferences. ${ }^{64}$ Although state legislatures attempt to enact intestacy statutes that fulfill the average testator's expectations, ${ }^{65}$ many people have unique testamentary preferences that diverge from the default distributional scheme of intestacy. ${ }^{66}$ Because testators are free to prepare estate plans that best fulfill their testamentary preferences, those whose preferred estate plans differ from the default scheme of intestacy can derive comfort and satisfaction from freedom of testation. ${ }^{67}$

In addition to testamentary freedom, the role of the estate planning attorney is another therapeutic aspect of the estate planning process. ${ }^{68}$ Typically, a lawyer assists the testator with preparing and implementing an estate plan. ${ }^{69}$ Along with providing legal advice regarding the technical aspects of estate planning, the lawyer can also serve as a therapeutic agent for her client by helping the testator prepare for and cope with the antitherapeutic aspects of the estate planning process. ${ }^{70}$ For example, the estate planning attorney can undertake strategies to minimize the pos-

62. See Glover, supra note 1, at 443.

63. See Glover, supra note 1, at 443-61.

64. Id. at 444-46.

65. See Bruce J. Winick, On Autonomy: Legal and Psychological Perspectives, 37 VILL. L. REV. 1705, 1766 (1992).

66. Jane B. Baron, Intention, Interpretation, and Stories, 42 DUKE L.J. 630, 652 (1992).

67. See Glover, supra note 1, at 445 (stating that autonomous choice improves testators' psychological well-being).

68. See id. at 446-50.

69. See Daphna Hacker, Soulless Wills, 35 LAW. \& SOC. INQUIRY 957, 979-80 (2010) (" $[\mathrm{L}]$ awyers dominate the will-production market, and most testators turn to them for advice in drafting their wills ....”).

70. Glover, supra note 1, at 448-50. 
sibility of estate disputes, provide realistic estimates of the cost and delay of probate, and diminish the testator's death anxiety by preparing an estate plan that fulfills her needs and quells some of her testamentary concerns. $^{71}$

The ritualistic nature of the will-execution ceremony also can positively affect the psychological well-being of those who prepare and implement estate plans. ${ }^{72}$ For instance, the exercise of testamentary power is an important event for many people; therefore, because the ceremony symbolizes the significance of the testamentary experience, the testator can derive satisfaction from the ritualistic nature of the will-execution process. $^{73}$ Additionally, while preparing an estate plan, the testator can experience anxiety because she must acknowledge the inevitability of her own death. ${ }^{74}$ However, by serving as a framework through which the testator can cope with her confrontation with mortality, the willexecution ceremony can diminish some of the negative psychological consequences of the testator's death anxiety. ${ }^{75}$

Finally, estate planning can prove therapeutic for the testator because the process can be a tool for self-expression. ${ }^{76}$ Either through the language of an estate planning document or by the act of providing for friends and family in an estate plan, ${ }^{77}$ the estate planning process can be an important self-expressive outlet for the testator. Testamentary selfexpression can produce a variety of positive psychological consequences. For example, the testator can express love and affection for friends and family, ${ }^{78}$ which is therapeutic for the testator because she can draw pleasure from making those she loves happy. ${ }^{79}$ Additionally, by benefit-

71. Id.

72. See id. at 450-55.

73. See Estate Planning for Human Beings, 3 InST. ON EST. PLAN. ๆ 69.1902 (1969) [hereinafter Estate Planning] (statement of Dean Willard H. Pedrick, panelist) ("The estate planning process ... ought to be a high ceremonial occasion because a client should be getting great intangible satisfactions about the[] significant decisions that he has made [and] that were embodied in the instruments [that] he leaves behind.”); see also John A. Warnick, The Ungrateful Living: An Estate Planner's Nightmare-The Trial Attorney's Dream, 24 LAND \& WATER L. REV. 401, 422-23 (1989) (explaining that the ceremonial aspect of will execution "may be important in fulfilling the client's unexpressed expectations.”).

74. See supra Part II.B.1.

75. See Glover, supra note 1, at 454-55.

76. Id. at 455 .

77. Id. at 455-56.

78. Id.

79. See Adam J. Hirsch, Bequests For Purposes: A Unified Theory, 56 WASH. \& LEE L. REV. 33, 52-53 (1999) ("When a testator bequeaths to persons, the satisfaction she derives from the transfer ... stems from what the economists, in their inimitable fashion, dub an interdependent utility 
ing certain organizations or causes in her estate plan, the testator can mold her posthumous reputation. ${ }^{80}$ Shaping one's public perception can be psychologically satisfying, and using one's estate plan to achieve one's desired posthumous reputation is therefore one therapeutic aspect of the estate planning process. ${ }^{81}$ In sum, the testator's opportunity for self-expression stands alongside freedom of testation, the role of the estate planning lawyer, and the will-execution ceremony as a therapeutic aspect of the estate planning process.

\section{THE THERAPEUTIC FUNCTION OF TESTAMENTARY FORMALITY}

Just as all testators must confront death during the estate planning process, those who prepare and implement estate plans typically employ wills as part of the process and therefore must comply with an assortment of formal will-execution requirements. ${ }^{82}$ Generally, these formalities require that a will be written, signed, and attested by at least two witnesses; however, some jurisdictions require other formalities as well. ${ }^{83}$ The primary purpose of these formalities is to ensure that the will accurately and reliably reflects the testator's true testamentary intent. ${ }^{84}$ Testamentary formality, however, may also serve other purposes. ${ }^{85}$

Because testamentary formality is a fundamental component of the estate planning process, the application of therapeutic jurisprudence to

function: Making her loved ones happy also makes the testator happy.”).

80. See id. at 53-54 ("An estate plan can serve as the final move in this social game, communicating to survivors how individuals prefer to be remembered.”).

81. Glover, supra note 1, at 456-58.

82. See DUKEMINIER ET AL., supra note 6, at 226-27.

83. Id. at 226

84. See In re Will of Ranney, 589 A.2d 1339, 1344 (N.J. 1991) (“The primary purpose of [will] formalities is to ensure that the document reflects the uncoerced intent of the testator.”). Legal scholars have identified four functions that will formalities serve in furtherance of formality's ultimate goal of fulfilling testamentary intent. First, by requiring the testator to leave behind a written, signed, and attested document that provides reliable evidence of testamentary intent, will formalities serve an evidentiary function. Second, the formal requirements of valid will execution serve a protective function by protecting the testator from fraud and undue influence. Third, the cautionary function of testamentary formality impresses upon the testator the importance of will execution and encourages careful planning and adequate deliberation. Finally, will formalities standardize the form of most wills, thus easing the administrative burden of probate courts. This fourth function of testamentary formality is called the channeling function. John H. Langbein, Substantial Compliance with the Wills Act, 88 HARV. L. REV. 489, 491-98 (1975).

85. See Peter M. Tiersma, Parchment, Paper, Pixels: Law and the Technologies of COMMUNICATION 60-62 (2010) (identifying the textualizing function); Mark Glover, Formal Execution and Informal Revocation: Manifestations of Probate's Family Protection Policy, 34 OKLA. City U. L. REV. 411, 431-40 (2009) (identifying the family protection function). 
the study of will formalities requires an analysis of how such formalities interact with and influence the therapeutic and antitherapeutic aspects of estate planning. Using this therapeutic jurisprudential framework, this section analyzes the role of will formalities in the estate planning process, including how they either bolster or diminish the therapeutic and antitherapeutic qualities of estate planning. Based on this analysis, this section argues that one additional purpose of testamentary formality is to promote the therapeutic aspects of estate planning. Indeed, because formal will-execution requirements enhance the overall therapeutic potential of the estate planning process, testamentary formality serves a therapeutic function.

\section{A. Therapeutic Aspects of Testamentary Formality}

A therapeutic jurisprudential analysis reveals that testamentary formality has therapeutic qualities. Such an analysis suggests that the therapeutic aspects of testamentary formality are those qualities of will formalities that either enhance the therapeutic aspects of estate planning or diminish the process's negative psychological consequences. When examined within this framework, testamentary formality can be seen as bolstering several of the positive psychological aspects of the estate planning process, including the doctrine of testamentary freedom, the counsel of an estate planning attorney, and the ritualistic nature of the will-execution ceremony. Testamentary formality therefore serves a therapeutic function because it promotes the overall therapeutic potential of estate planning.

\section{Testamentary Safe Harbor}

Freedom of testation can be a source of great psychological benefit because the testator can draft a will and dispose of her estate as she chooses. ${ }^{86}$ This psychological benefit is possible only if the testator has some expectation that her testamentary preferences will be fulfilled. Without a guarantee that the testator's wishes will be respected, testamentary freedom's therapeutic potential is diminished. Specifically, if the law provided no guidance regarding valid will execution, the testator would bear the responsibility of successfully expressing the legal significance of her action to the probate court. ${ }^{87}$ The testator would then have

86. See supra Part II.B.2.

87. See Lon L. Fuller, Consideration and Form, 41 CoLUM. L. REV. 799, 802 (1941) (explain- 
no assurance that the court would recognize her words as a valid exercise of testamentary power, thus weakening the therapeutic consequences of testamentary freedom.

Will formalities address this potential uncertainty of testamentary freedom by providing a safe harbor through which the testator can effectively communicate testamentary intent. ${ }^{88}$ Legal formalities generally create a safe harbor in which to perform acts of legal significance because they provide "channels for the legally effective expression of intention." 99 Put differently, "form[ality] offers a legal framework into which the party," who desires to perform an act of legal significance, such as entering into a contract or executing a will, "may fit his actions .....90 By requiring the testator to express her testamentary intent in the prescribed form of a written, signed, and attested document, the law of wills reduces the uncertainty of valid will execution and provides a method of exercising testamentary power that a probate court will recognize as legally valid. ${ }^{91}$

Satisfying the requirements of the safe harbor is not conclusive evidence of testamentary intent, as a contestant can still argue that the decedent did not intend to execute a will. ${ }^{92}$ However, the safe harbor makes the contestant's task difficult because compliance with the prescribed formalities triggers a presumption of testamentary intent that the contestant must overcome. ${ }^{93}$ Testamentary formality therefore contributes to

ing that "[o]ne planning to enter a legal transaction faces a ... problem" because "[h]is mind first conceives an economic or sentimental objective" and "[h]e must then ... cast about for the legal transaction ... which will most nearly accomplish these objectives.”); John H. Langbein, Excusing Harmless Errors in the Execution of Wills: A Report on Australia's Tranquil Revolution in Probate Law, 87 Colum. L. REV. 1, 4 (1987) ("Without prescribed formalities, the testator would be left to grope for his own means of persuading the probate court that his intentions were final and volitional.”); James Lindgren, The Fall of Formalism, 55 ALB. L. REV. 1009, 1031 (1992) (“In a system without the safe harbor of a will, a testator might have to go to extraordinary lengths to ensure that her wishes were followed after her death.”).

88. Langbein, supra note 87, at 4; Lindgren, supra note 87, at 1031.

89. Fuller, supra note 87 , at 801.

90. Id.

91. See Langbein, supra note 84, at 494 (explaining that because of will formalities the testator "does not have to devise for himself a mode of communicating his testamentary wishes to the court, and to worry whether it will be effective.”); Lindgren, supra note 87, at 1031 (“One of the positive effects of formalism is that known acts produce known results. Formalities bring consistency and protection against arbitrariness.").

92. See John H. Langbein \& Lawrence W. Waggoner, Reformation of Wills on the Ground of Mistake: Change of Direction in American Law?, 130 U. PA. L. REV. 521, 541-42 (1982) (discussing "the so-called 'sham will' cases").

93. Id. 
the therapeutic potential of testamentary freedom by creating this safe harbor for the exercise of testamentary power, which raises a presumption of testamentary intent and provides the testator the peace of mind of knowing that her testamentary preferences will be respected. ${ }^{94}$

\section{Incentive to Seek Legal Assistance}

In addition to freedom of testation, the counsel of a lawyer during the preparation of a testamentary scheme and the execution of a will can have therapeutic consequences for the testator. Although the estate planning attorney can serve as a therapeutic agent for her client, the law does not require that the testator consult a lawyer. The formal requirements of valid will execution, however, foster the therapeutic potential of estate planning by encouraging the testator to seek legal assistance during the will-execution process. ${ }^{95}$ Certainly, the testator may engage a lawyer for many reasons. ${ }^{96}$ For example, the client may seek legal advice to minimize estate taxes or reduce the risk of a will contest. ${ }^{97}$ But, in addition to the variety of other concerns that encourage the testator to seek legal advice, the formality of will execution incentivizes the consultation of an estate planning attorney. ${ }^{98}$

Will formalities encourage the testator to consult a lawyer in two ways. First, because the testator must comply with a variety of technical requirements, the will-execution process is "a fertile field for error.",99 As a result, the testator may seek the aid of a lawyer to guide her through the process of complying with the prescribed formalities. ${ }^{100}$ Second, will

94. See Langbein, supra note 87, at 4 ("The greatest blessing of the Wills Act formalities is the safe harbor that they create" because "[t]he testator who complies with [them] assures his estate of routine probate in all but exceptional circumstances.”). But see infra Part II.B.

95. See Lawrence M. Friedman, The Law of the Living, the Law of the Dead: Property, Succession, and Society, 1966 WIS. L. REV. 340, 368 (1966); Adam J. Hirsch, Inheritance and Inconsistency, 57 OHIо ST. L.J. 1057, 1066-67 n.31 (1996) (“[T]he intervention of attorneys" in the willexecution process, "though not mandatory, is encouraged simply by the requirement that testators fulfill the technical formalities.”); Langbein, supra note 84, at 494 n.26 (stating that the Wills Act forms encourage the use of lawyers).

96. See Love \& Sterk, supra note 51, at 551-54.

97. Id. at 552.

98. See Friedman, supra note 95, at 368.

99. Gerry W. Beyer, Avoiding the Estate Planning "Blue Screen of Death"-Common NonTax Errors and How to Prevent Them, 1 Est. PLAN. \& CMTY. Prop. L.J. 61, 93 (2008).

100. Hirsch, supra note 95, at 1066-67 n.31; see also William F. Fratcher, Toward Uniform Succession Legislation, 41 N.Y.U. L. REV. 1037, 1081 (1966) ("Contracts affecting succession ... are likely to cause much suffering if entered into without competent advice as to their effects. Consequently, it seems desirable to impose [formal] requirements upon the making of such 
formalities encourage the use of an estate planning attorney by impressing upon the testator the importance and legal significance of preparing an estate plan and executing a will. ${ }^{101}$ Without formal requirements, the testator may not fully consider the significance of executing a will and therefore may minimize the prudence of having legal assistance during the will-execution process. Because will formalities provide the willexecution process a level of technical complexity and encourage the testator to fully consider the legal significance of her actions, the testator more likely recognizes the need for legal guidance during the willexecution process, ${ }^{102}$ and, as a result, the estate planning attorney has a greater opportunity to be a therapeutic agent for the testator.

\section{Elements of the Will-Execution Ceremony}

The ceremonial, or ritualistic, nature of the will-execution process positively affects the testator's psychological well-being in a variety of ways. ${ }^{103}$ This ritualistic nature of the will-execution process results from the statutorily prescribed will formalities. Indeed, the formal requirements of valid will execution-which mandate that a will be written, signed by the testator, and attested by at least two witnesses ${ }^{104}$ —are the foundation of the will-execution ceremony.

Although the term may be ascribed a variety of meanings, "[r]itual can be defined as the performance of a more or less invariant sequence of formal acts and utterances not entirely encoded by the performer."105 With this definition in mind, formalism stands out as a primary ritualistic component because ritual uses "a structured set of words and bodily gestures," that are "invariant" and "governed by complex codes of orchestration ....”106 The execution of a will undoubtedly possesses this ritu-

contracts that are so difficult that they cannot be met without the advice of counsel.”).

101. See Langbein, supra note 84, at 495 ("One purpose of many of the forms is to impress the testator with the seriousness of the testament ....”).

102. See Friedman, supra note 95, at 367-68 ("The formalities of executing a will are useful ones" because "[t]hey impress the testator with the solemnity of his acts; they ensure a standard written document, . . . they eliminate most of the dangers of forgery and fraud; [and] they encourage the use of middlemen (lawyers) who can help plan a rational, trouble-free disposition of assets.”).

103. See supra Part II.B.2.

104. DUKEMINIER ET AL., supra note 6, at 226.

105. Andrew J. Cappel, Bringing Cultural Practice Into Law: Ritual and Social Norms Jurisprudence, 43 SANTA CLARA L. REV. 389, 408-09 (2003).

106. See id. at 409 ("[T]he ritual process is highly conventionalized, and employs a 'restricted code' of communication" that is "characterized by: (1) a limited means of expression; (2) a correspondingly limited ability to convey information; and (3) a resulting sharp limitation on the freedom 
alistic characteristic. ${ }^{107}$ The formalism of testation closely mirrors typical ritualistic formalism because the law of wills prescribes the process by which a testator must execute a will, and the testator must precisely follow these mandated rules. Put differently, the statutes governing will execution serve as the "complex codes of orchestration"108 that the testator must invariably follow. ${ }^{109}$

A second general characteristic of ritual is the use of symbolism ${ }^{110}$ and "notions of the sacred" Again, will formalities provide the will-execution process this ritualistic trait because the requirement of a written, signed, and attested document sets the process apart from the commonplace tasks of life. Formalities symbolize the importance of the testator's actions and provide the process a general aura of solemnity. ${ }^{112}$ For example, the requirement that a will be written signifies the importance of the testamentary act by eliminating the possibility of oral testamentary dispositions. ${ }^{113}$ Because "[w]riting has always been regarded as the most solemn form of expression," 114 the testator more likely recognizes the importance and legal significance of creating a will, which, in turn, contributes to the ritualistic

of receivers of ritual communication to interpret the meaning of this communication in more than one way.”); Steven Hartwell, Humor, Anger, Rules, and Rituals, 13 CliniCAL L. ReV. 327, 370-71 n.102 (2006).

107. See Langbein, supra note 84, at 489 ("The law of wills is notorious for its harsh and relentless formalism.”); Lindgren, supra note 87, at 1010 (“Formalism may be falling, but it isn’t dead.”).

108. Cappel, supra note 105, at 409.

109. See Langbein, supra note 84, at 489 (explaining that " [t]he Wills Act prescribes a particular set of formalities for executing one's testament" and that "once a formal defect is found, AngloAmerican courts have been unanimous in concluding that the attempted will fails.").

110. Cappel, supra note 105, at 410; Hartwell, supra note 106, at 370.

111. Hartwell, supra note 106, at 370-71 n.102 (explaining that "rituals appear to take place in time and place apart from everyday activity”); see Cappel, supra note 105, at 410 ("[S]acrality ... distinguish[es] ritualized from non-ritualized (everyday) activity.”).

112. See Lloyd Bonfield, Reforming the Requirements for Due Execution of Wills: Some Guidance from the Past, 70 TuL. L. REV. 1893, 1907 (1996); Ben Kusmin, Note \& Comment, Swing Low, Sweet Chariot: Abandoning the Disinterested Witness Requirement for Advance Directives, 32 AM. J.L. \& MED. 93, 99 (2006) (explaining that the execution of a will "has pomp and circumstance" that routine activities do not).

113. See Fuller, supra note 87, at 800 (explaining that the requirement of a writing "induc[es] [a] circumspective frame of mind."); Langbein, supra note 84, at 495 ("The requirements of writing and signature are ... the primary cautionary formalities. Writing is somewhat less casual than plain chatter. As we say in a common figure of speech, 'talk is cheap.'”).

114. Nelson \& Starck, supra note 43, at 349; see Ashbel G. Gulliver \& Catherine J. Tilson, Classification of Gratuitous Transfers, 51 YALE L.J. 1, 14 (1941) ("[T]here is certain ritual value in writing out [a] document...."); Langbein, supra note 84, at 519 ("Although some modes of electronic communication can perform some of the functions of writing ... they lack the solemnity and finality of a signed document.”). 
character of the will-execution process.

The signature requirement also contributes to the symbolism and solemnity of the will-execution process. Like the writing requirement, the signature requirement represents the finality of the testator's actions and is meant to impress upon the testator the legal significance of preparing a will. ${ }^{115}$ Traditionally, people use their signatures as symbols of the finality of their actions, particularly when completing documents of legal import. ${ }^{116}$ As such, during the will-execution process, the testator likely recognizes the symbolism and legal significance of her signature. ${ }^{117}$ The testator's placement of her signature upon the will is therefore a symbolic act that serves as one element of the will-execution ceremony.

Finally, the attestation requirement, perhaps more so than the other formalities, distinguishes the exercise of testamentary power from daily routine. ${ }^{118}$ As Professor Lon Fuller explains in his classic article examining legal formalities, the requirements of attestation serve the same purpose as the formal requirement of the seal, which was a "symbol in the popular mind of legalism and weightiness" and "was an excellent device for inducing [a] circumspective frame of mind."119 Attestation achieves this symbolic quality largely by introducing outsiders into the will-

115. See Gulliver \& Tilson, supra note 114 , at 5 (explaining that "[t]he signature tends to show that the instrument was finally adopted by the testator as his will”); Langbein, supra note 87, at 3 ("Signature ... caution[s] the testator about the seriousness and finality of his act."); see also Chad Michael Ross, Comment, Probate-Taylor v. Holt: The Tennessee Court of Appeals Allows a Computer Generated Signature to Validate a Testamentary Will, 35 U. MEM. L. REV. 603, 608 (2005) (explaining that the testator's signature symbolizes the finality of the testator's actions). The subscription formality, which requires the testator to sign at the end of her will, can also add to the ritualistic character of the will-execution process. See Gulliver \& Tilson, supra note 114, at 5-6.

116. One commentator has argued that the "growing use of signature in routine petty transactions has reduced" the significance of the signature requirement. Langbein, supra note 84, at 518. "However, it could be argued that the routine use of signature as an implementing act in ordinary business transactions may enhance its 'ritual' impact, because the omission of a signature from a document produces an inference of a lack of finality of intention.” C. Douglas Miller, Will Formality, Judicial Formalism, and Legislative Reform: An Examination of the New Uniform Probate Code "Harmless Error" Rule and the Movement Toward Amorphism, Part One: The Wills Act Formula, the Rite of Testation, and the Question of Intent: A Problem in Search of a Solution, 43 FLA. L. REV. 167, 265 (1991).

117. Langbein, supra note 84, at 518 ("Most people would not lightly sign anything captioned 'Last Will and Testament.'”).

118. See Miller, supra note 116, at 260-61 (explaining that attestation contributes most to the will-execution ritual "because it induces the testator to select witnesses to the testament and otherwise to engage in deliberate, premeditated conduct ...."); see also Langbein, supra note 84, at 495 ("The formalities associated with attestation" transform "[t]he execution of the will . . into a ceremony impressing the participants with its solemnity and legal significance.”).

119. Fuller, supra note 87, at 800. 
execution process. ${ }^{120}$ Indeed, the inclusion of witnesses in the testamentary experience greatly enhances the ritualistic nature of will execution. ${ }^{121}$ The formality of attestation together with the signature and writing requirements therefore serve as the elements of the will-execution ceremony and distinguish the creation of a will from other mundane and trivial activities.

In addition to serving as the foundation of the testamentary ritual, formalities also provide the will-execution process a ceremonial character by encouraging the testator to seek legal assistance. ${ }^{122}$ The estate planning lawyer in turn reinforces the ritualistic qualities of the willexecution process in two ways. First, the testator's lawyer inevitably stresses the importance of compliance with the prescribed formalities ${ }^{123}$ and therefore perpetuates the invariant formalism that is a primary characteristic of ritual. ${ }^{124}$ Second, the testator's lawyer contributes to the symbolism and formality of the will-execution ceremony, thereby setting the execution of a will further apart from the inconsequential tasks of daily life. For example, the mere presence of the lawyer during will execution adds a degree of formality to the ceremony, and the execution of a will is further distinguished from the testator's normal routine when the ceremony takes place in the lawyer's office rather than a more informal setting, such as the testator's home. ${ }^{125}$ Finally, the estate planning attorney may insist that the testator comply with nonmandatory formalities, such as notarization, which provides the will-execution ceremony even greater formality. ${ }^{126}$

In sum, the formal requirements of valid will execution serve as the

120. Langbein, supra note 84, at 521.

121. Id.

122. See supra note 95 and accompanying text.

123. Even in jurisdictions that authorize holographic wills, which require a reduced level of formality, estate planning attorneys perpetuate the formalism of will execution by requiring the testator to comply with all of the formalities of traditional attested wills. See Langbein, supra note 84, at 524.

124. See supra notes 109-12 and accompanying text.

125. The lawyer's office sets the will-execution ceremony apart from the normal routine of life because "the moment of executing a will . . . may be one of the few times that [the testator] ever visits a law office." Roger W. Andersen, Will Executions: A Modern Guide, 18 AM. J. TRIAL ADVOC. 57, 85-86 (1994). Although there is no requirement that the will-execution ceremony take place in a law office, “[t]estators now tend to sign their wills . . . in a lawyer's office.” Bruce H. Mann, SelfProving Affidavits and Formalism in Wills Adjudication, 63 WASH. U. L.Q. 39, 49 (1985).

126. See DUKEMINIER ET AL., supra note 6, at 242-43 (explaining that "the careful lawyer in our highly mobile society should draw a will and have it executed in a manner that satisfies the formal requirements in all states" rather than having it executed in a manner that complies with formalities required in the state of execution). 
elements of the will-execution ceremony and provide the execution of a will a ritualistic character. The formalities lend will execution its ceremonial nature by symbolizing the importance and legal significance of the testamentary act. Moreover, the estate planning attorney who assists the testator during the will-execution ceremony perpetuates the ritualistic character of executing a written, signed, and attested document. Testamentary formality therefore serves a therapeutic function not only by providing the testator a safe harbor for the valid exercise of testamentary freedom and encouraging the testator to seek legal assistance, but also by lending the will-execution process its ritualistic character.

\section{B. Antitherapeutic Aspects of Testamentary Formality}

Although testamentary formality promotes several of the positive psychological aspects of estate planning, a therapeutic jurisprudential analysis also recognizes that will formalities may have antitherapeutic consequences. Mirroring its therapeutic qualities, testamentary formality's antitherapeutic aspects are those characteristics of will formalities that either magnify the antitherapeutic consequences of estate planning or diminish the positive psychological qualities of the process. When analyzed from this therapeutic jurisprudential perspective, one primary antitherapeutic consequence of testamentary formality emerges, namely that formality represents an impediment to the exercise of testamentary freedom.

Testamentary freedom allows the testator to craft an estate plan that best meets her testamentary preferences. ${ }^{127}$ This freedom can have a variety of positive psychological consequences for the testator. ${ }^{128}$ However, although the testator enjoys broad liberty to craft the substance of her estate plan, the law has long placed restrictions on the form of the testator's will. ${ }^{129}$ The testator cannot execute a will by any method that she chooses; rather, she must comply with the requirements imposed by testamentary formality. ${ }^{130}$ Moreover, the law traditionally has mandated strict literal compliance with these formalities, which generally requires the invalidation of a will for any failure to comply with the prescribed

\footnotetext{
127. See supra Part II.B.2.

128. See supra Part II.B.2.

129. See Friedman, supra note 95, at 365 (““'[F]ree testation’ refers only to the choice of people who are to share in one's estate; it does not apply to the manner in which the document of gift is drawn up.").

130. DUKEMINIER ET AL., supra note 6, at 226-27.
} 
formalities, no matter how small or technical the formal defect. ${ }^{131}$

Because the testator must strictly comply with the formal requirements of will execution, testamentary formality represents an impediment to the exercise of testamentary freedom. ${ }^{132}$ Indeed, the testator may view compliance with the prescribed will formalities as a burden. As such, "will making may seem daunting and the formality and ritualized nature of the venture may act as a barrier for people who might otherwise make a will." "133 Additionally, the strict compliance requirement frequently frustrates testamentary intent, as courts have long invalidated wills despite clear and convincing evidence that the testator intended to exercise testamentary freedom. ${ }^{134}$ As one New Jersey judge explained, "A writing may express clearly the wish or intention of a decedent, but if the statutory formalities have not been followed, it is not a valid will, because it cannot be a question of what he intended to do, but whether he has actually followed the provisions of the statute." 135

In sum, when coupled with a rule of strict compliance, testamentary formality represents an impediment to the exercise of testamentary freedom because it can dissuade attempts to execute wills and is a basis to invalidate formally defective testamentary documents. Because testamentary formality impedes the exercise of testamentary freedom, it is also a barrier to the testator's enjoyment of the positive psychological consequences of estate planning. This negative psychological consequence of will formalities therefore represents one antitherapeutic aspect of testamentary formality.

Despite this antitherapeutic effect, testamentary formality maintains its overall therapeutic function. In fact, this antitherapeutic quality of impeding testamentary freedom is not primarily a consequence of testamentary formality, but instead is properly understood as a negative psychological consequence of the formalism that mandates strict literal

131. See id. at 228.

132. Glover, supra note 85, at 431-34; see Gulliver \& Tilson, supra note 114, at 18 ("Doctrinal barriers to the effectuation of intent are raised most frequently by the requirements of the statutes of wills ....”).

133. Joel C. Dobris \& STEWART E. STERK, Ritchie, ALFord AND EFFLAND's Estates AND TRUSTS: CASES AND MATERIALS 194-95 (9th ed. 1998).

134. See Mann, supra note 125, at 39 ("Courts routinely invalidate wills because of minor defects in execution, even when no one questions that the will represents the wishes and intent of the testator.”); see, e.g., In re Will of McElwaine, 18 N.J. Eq. 499, 504 (N.J. Prerog. Ct. 1867) ("I have no doubt that this paper was intended by the testatrix as her will, and that but for the [will formality] statute, it ought to have effect given to it so far as she had legal power to make a will.”).

135. Murray v. Lewis, 121 A. 525, 527 (N.J. Ch. 1923). 
compliance with the prescribed formalities. The formalities of writing, signature, and attestation do not themselves present an obstacle to the testator's enjoyment of testamentary freedom. Instead, the rule of strict compliance is the hurdle over which testators must pass before exercising their freedom of testation.

If the rule of strict compliance were replaced by a more lenient rule of formal compliance-such as the harmless error rule or the substantial compliance doctrine - testamentary formality would not significantly impede the exercise of testamentary freedom because, pursuant to such relaxed compliance rules, a will would be valid despite minor formal compliance errors. ${ }^{136}$ Absent the requirement that the testator strictly comply with the prescribed will formalities, the testator would more likely execute a valid will and more easily exercise the freedom of testation. ${ }^{137}$ When viewed from this perspective, the rule of strict compliance represents the testator's most significant barrier to the exercise of testamentary freedom. The positive psychological consequences of will formalities therefore outweigh their antitherapeutic qualities, and, as a result, testamentary formality serves a therapeutic function.

\section{THE THERAPEUTIC EFFECT OF REFORM}

After identifying the law's therapeutic and antitherapeutic consequences, the second step of a therapeutic jurisprudential analysis is to examine how the law's overall therapeutic potential can be maximized. ${ }^{138}$ Instead of suggesting new reforms of the will-execution process, this section analyzes two developments that threaten to undermine the therapeutic function of testamentary formality by diminishing the role of formality in the law of succession. Critics increasingly admonish will formalities for undermining testamentary intent because, under the traditional rule of strict compliance, any minor defect invalidates the will. ${ }^{139}$

\footnotetext{
136. See infra Part IV.B.

137. See Melanie B. Leslie, The Myth of Testamentary Freedom, 38 ARIz. L. REv. 235, 274 (1996) (explaining that by reforming the formal requirements of will execution "the drafters [of the Uniform Probate Code] believe they have removed a needless barrier to the probate of documents that embody testamentary intent.").

138. See Schultz, supra note 13, at 54 (stating that it is possible to maximize the law's overall therapeutic potential by "incorporat[ing] these social science findings into the law-making process so as to fine-tune the outcomes to the desired therapeutic level").

139. See Stevens v. Casdorph, 508 S.E.2d 610, 611-12 (W. Va. 1998) (Workman, J., dissenting) (criticizing the majority opinion, which upheld a strict compliance standard, for "tak[ing] a very technocratic approach to the law [and] slavishly worshipping form over substance"); Langbein, supra note 84 , at 489 .
} 
Such criticism fuels a law reform movement that has proposed two types of reforms. One suggested reform reduces the level of formality so as to minimize the formal burdens of will execution. ${ }^{140}$ The second proposed reform relaxes the insistence on strict literal compliance, thereby allowing validation of a formally deficient testamentary document if the testator clearly intended to execute a will. ${ }^{141}$

Both the reduction of testamentary formality and the relaxation of strict testamentary formalism diminish formality's role in the process of posthumous wealth transmission. Because will formalities foster the therapeutic potential of estate planning, any changes that lessen formality's role in the law of succession could undermine the therapeutic function of will formalities. A therapeutic jurisprudential analysis of testamentary formality should therefore explore the potential therapeutic and antitherapeutic consequences of these reforms.

\section{A. Reduced Testamentary Formality}

The first proposed reform of the law of wills that threatens to undermine the therapeutic function of will formalities is the reduction of testamentary formality. Legal scholars and policymakers have proposed to implement this general reform in a variety of ways. First, as recommended by the Uniform Law Commission, the number of ancillary formalities, or those other than the primary formalities of writing, signature, and attestation, could be reduced. Second, the primary formality of attestation could be eliminated, as some in the legal academy have suggested. Finally, as authorized by the 2008 amendments to the Uniform Probate Code (UPC), wills that lack attestation could be valid if witnessed by a notary public.

\section{Reduction of Ancillary Formalities}

In addition to the primary will formalities of writing, signature, and attestation, ${ }^{142}$ a testator traditionally must comply with a variety of ancillary formalities to validly execute a will. ${ }^{143}$ For example, some states

\footnotetext{
140. See, e.g., James Lindgren, Abolishing the Attestation Requirement for Wills, 68 N.C. L. REV. 541, 542 (1990) (proposing the abolition of the attestation requirement).

141. See, e.g., Langbein, supra note 84, at 489 (advocating for substantial compliance); Langbein, supra note 87 , at 6-7 (arguing in favor of the harmless error rule).

142. DUKEMINIER ET AL., supra note 6, at 226.

143. See Langbein, supra note 84 , at 490 .
} 
impose a presence requirement, which mandates that the testator and the attesting witnesses be in each other's physical presence when the will is signed. ${ }^{144}$ Other ancillary will formalities include subscription, which requires that the testator affix her signature to the end of the testamentary document, and publication, which requires that the testator announce to the attesting witnesses that the document before them is her will. ${ }^{145}$

Despite the long history of these ancillary formalities, the drafters of the 1969 UPC broke from tradition and removed the presence, subscription, and publication requirements from the list of required willexecution formalities. ${ }^{146}$ The official comment to the relevant provision describes the effect of this change: "The formalities for execution of a witnessed will have been reduced to a minimum."147 The official comment continues by explaining the purpose of this reform: "The intent is to validate wills which meet the minimal formalities of the statute."148 Thus, the drafters of the UPC were concerned with validating testamentary documents that are genuine expressions of testamentary intent but which do not comply with the previously required ancillary formalities. As Professor John Langbein explains, "Doubtless the draftsmen balanced the injustice brought about by technical violations of the publication and presence requirements and decided that the ... value of those two former requisites was not worth the price in wills invalidated for defective compliance."149

This rationale underlying the reduction of ancillary will formalities corresponds nicely with one antitherapeutic consequence of testamentary formality. Specifically, when examined from a therapeutic jurisprudential perspective, the reduction of ancillary testamentary formality directly addresses the role that formalities play in impeding the exercise of testamentary freedom. As discussed previously, freedom of testation can positively affect the psychological well-being of the testator; ${ }^{150}$ however,

\footnotetext{
144. DUKEMINIER ET AL., supra note 6, at 233.

145. Id. at 243 n. 12 .

146. See UnIF. Probate Code $\S 2-502$ (amended 2008), 8 U.C.L.A. 136 (Supp. 2012).

147. Id. § 2-502 cmt., 8 U.L.A. 351.

148. Id.

149. Langbein, supra note 84, at 511; see also Pamela R. Champine, My Will Be Done: Accommodating the Erring and the Atypical Testator, 80 NEB. L. REV. 387, 392 (2001) (explaining that the reduction of ancillary will formalities was implemented "[t]o minimize the situations in which imposition of formalities will preclude probate of instruments intended to constitute wills ...."); Leslie, supra note 137, at 242 (explaining that the "changes were made to ensure courts would 'validate the will whenever possible'”).

150. See supra Part II.B.2.
} 
will formalities impose a technical hurdle over which the testator must pass to validly exercise this freedom. ${ }^{151}$ This consequence of formality is antitherapeutic because it minimizes the therapeutic potential of testamentary freedom. The elimination of the presence, publication, and subscription requirements diminishes this antitherapeutic effect by removing some of the obstacles that a testator must navigate to exercise freedom of testation. ${ }^{152}$ In this respect, the reduction of ancillary testamentary formality is a therapeutic reform of the law of wills.

This increased access to testamentary freedom, together with the impact of reduced ancillary formality on other therapeutic and antitherapeutic qualities of will formalities, produces a net therapeutic result. Consider, for example, the therapeutic consequence of the safe harbor that formalities create for the exercise of testamentary freedom. Because compliance with the prescribed formalities reliably signals that the testator intended the document to be a will, the testator is assured that her testamentary intent will be fulfilled. ${ }^{153}$ Therefore, testamentary formality, and the safe harbor that it creates, bolsters the therapeutic qualities of testamentary freedom. Although elimination of some primary formalities likely would diminish the therapeutic quality of the testamentary safe harbor, ${ }^{154}$ reduction of ancillary will formalities would not weaken the testator's assurance that her testamentary preferences will be fulfilled. ${ }^{155}$ Indeed, because the writing, signature, and attestation requirements generally create a reliable safe harbor, ${ }^{156}$ state legislatures can safely remove some or all of the ancillary formalities from their state's probate code "without reducing the certainty about which writings will and will not qualify" for the protections of the safe harbor. ${ }^{157}$

Consider also the positive psychological consequences of the will-

151. See supra notes $132-36$ and accompanying text.

152. See Champine, supra note 149, at 393 ("Reduction of formalities limits the possibility that defective execution will preclude probate ...."); Lindgren, supra note 140, at 568 ("These arguably nonpurposive rules can easily derail an innocent testator and should be eliminated even if the attestation requirement were retained.").

153. See supra Part III.A.1.

154. See infra Part IV.A.2 (arguing that complete abolition of the attestation requirement would negatively affect the positive psychological consequences of the will-execution process).

155. See Champine, supra note 149, at 393 (noting that the "[r]eduction of formalities limits the possibility that defective execution will preclude probate ....”).

156. See Langbein, supra note 84, at 511 (explaining that the reduction of ancillary formality "suggest[s] that it is primarily the evidentiary and channeling purposes of the Wills Act which survive in modern times.”); Lindgren, supra note 87, at 1031-32 (arguing that the safe harbor would remain even if the attestation requirement were abolished).

157. Champine, supra note 149, at 393. 
execution ceremony. ${ }^{158}$ The ritualistic nature of the will-execution process can positively influence the testator's psychological well-being. ${ }^{159}$ The process achieves this ceremonial quality through the requirement that the testator comply with various formalities. ${ }^{160}$ Because they are among the elements that comprise the will-execution ceremony, elimination of ancillary testamentary formalities could diminish the ritualistic nature of will execution. However, like the secondary importance of the presence, publication, and subscription requirements in creating the testamentary safe harbor, ancillary will formalities likewise are less significant in creating the ceremony of will execution. Instead, the primary formal requirements of writing, signature, and attestation are the main components of the will-execution ceremony, ${ }^{161}$ and, in this regard, the participation of witnesses is of utmost significance. ${ }^{162}$ Therefore, while attestation "is the major factor in ceremonializing the execution," the ancillary formalities of presence, subscription, and publication contribute only incrementally to the ritual of will execution. ${ }^{163}$ As a result, the reduction of ancillary formalities would not reduce the therapeutic potential of the will-execution ceremony.

As demonstrated above, a therapeutic jurisprudential analysis reveals that the reduction of ancillary testamentary formality is a therapeutic reform of the law of wills. The reduction of ancillary formality bolsters the overall therapeutic potential of will execution by removing some of the obstacles that the testator faces when exercising testamentary freedom. In fact, the goal of this reform is to significantly alleviate this antitherapeutic consequence of testamentary formality. ${ }^{164}$ Also contributing to the net therapeutic result is that this reform neither magnifies testamentary formality's other antitherapeutic qualities, nor diminishes its positive psychological consequences. Because the reduction of ancillary testamentary formality increases the law's therapeutic potential by eliminating barriers to the exercise of testamentary freedom, while also maintaining the therapeutic status quo with respect to other consequences of testamentary formality, the elimination of the presence, subscription, and

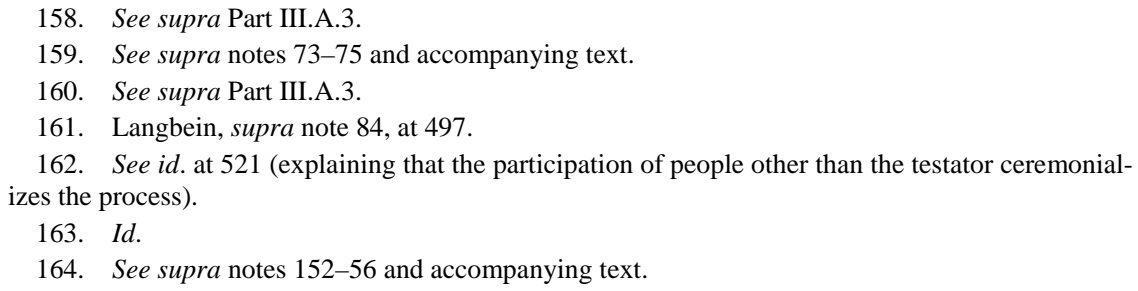


publication requirements is an overall therapeutic reform of the law of succession.

\section{Elimination of the Attestation Requirement}

Similar to the reduction of ancillary will formalities, Professor James Lindgren has argued for the elimination of the attestation requirement. ${ }^{165}$ This reform of the will-execution process would, however, negatively affect the therapeutic function of testamentary formality. As previously discussed, one therapeutic consequence of will formalities is that they provide a safe harbor for the exercise of testamentary power. ${ }^{166}$ The testator knows that if she complies with the required formalities, her testamentary intent will be legally recognized. ${ }^{167}$ As a result, the knowledge that her testamentary preferences will be honored bolsters the therapeutic consequences of testamentary freedom. ${ }^{168}$ By contrast, when coupled with a rule of strict compliance, testamentary formality can also significantly impede the exercise of testamentary freedom. ${ }^{169}$ This consequence of testamentary formality can negatively affect the testator's psychological well-being because her testamentary preferences might be ignored due to a minor formal defect. ${ }^{170}$

The elimination of the attestation requirement would affect these therapeutic and antitherapeutic qualities of testamentary formality by expanding the scope of the testamentary safe harbor. In other words, a broader range of documents would fall within the safe harbor's protection. No longer would a testamentary document need to be attested by two witnesses - any signed writing would satisfy the safe harbor's requirements. This expansion would have two consequences. First, the safe harbor could become overinclusive because documents that were not intended to be testamentary in nature could be considered legally valid wills. ${ }^{171}$ Second, as the proponents of this reform intend, the burdens of

165. Lindgren, supra note 140, at 543; Lindgren, supra note 87, at 1024-30. Other scholars agree. See, e.g., C. Douglas Miller, Will Formality, Judicial Formalism, and Legislative Reform: An Examination of the New Uniform Probate Code "Harmless Error" Rule and the Movement Toward Amorphism, Part Two: Uniform Probate Code Section 2-503 and a Counterproposal, 43 FLA. L. REV. 599, 717 (1991).

166. See supra Part III.A.1.

167. See supra Part III.A.1.

168. See supra Part III.A.1.

169. See supra Part III.B.

170. See supra Part III.B.

171. See Miller, supra note 116, at 277 (explaining that "[c]ompliance with the attestation requirement produces a 'virtually unmistakable testamentary act'” but that "[c]ompliance with the re- 
bringing a document within the safe harbor would ease because the testator would have to comply with fewer formalities to validly execute a will. ${ }^{172}$

The expanded scope of the testamentary safe harbor, perhaps to the point of overinclusiveness, would not affect the therapeutic consequences of testamentary freedom. Those who desire to execute a will would still have a definitive method of entering the safe harbor. The lower burden of placing a document within the safe harbor, however, likely would affect the therapeutic consequences of testamentary freedom. On the one hand, without an attestation requirement, the testator would have to overcome one fewer hurdle to fall within the safe harbor, thereby providing the testator more confidence that she will enjoy the safe harbor's protections. ${ }^{173}$ On the other hand, the safe harbor's protections would weaken because the testator would have less certainty that documents that fall within the safe harbor would be recognized as legally valid wills. ${ }^{174}$ Indeed, even when a decedent qualifies for the safe harbor, a contestant of the will can argue nonetheless that the decedent did not intend to execute a will. 175

Put succinctly, the safe harbor would become less safe. Without the precisely defined safe harbor that attestation provides, the issue of whether a decedent intended a particular document to be testamentary in nature would more likely be disputed ${ }^{176}$ and a contestant of the will would more easily overcome the presumption of testamentary intent that the safe harbor triggers. Consequently, some documents that were in-

quirements for a holographic will," which does require attestation, “often fails to distinguish the writing intended to be given effect as a will from the signed and dated letter, memorandum, or draft containing statements about the disposition of the decedent's property.").

172. See Champine, supra note 149, at 393 ("Reduction of formalities limits the possibility that defective execution will preclude probate....”); Mary Louise Fellows, In Search of Donative Intent, 73 IOWA L. REV. 611, 614 (1988) ("The reduction in legal formalities minimizes the number of cases in which property owners take actions indicating that they probably intend to made a donative transfer, but, nevertheless, fail to meet the formalities . . ..”).

173. See Lindgren, supra note 140, at 572 (explaining that if the attestation requirement were abolished "[l]itigation about formalities would largely disappear . . ..").

174. See id. (explaining that if the attestation requirement were abolished "litigation about testamentary intent would increase" and explaining further that "instead of judging litigation over whether there was adequate publication or whether the witnesses signed before the testator, the courts would try to decide whether a signed writing disposing of the testator's property was actually intended to be his will."); see also Langbein, supra note 87, at 6 (explaining that "high levels of formality... enhance the safe harbor that is created for the careful testator who complies fully ....”).

175. Lindgren, supra note 140, at 572.

176. See id. 
tended to be wills and that fulfilled the formal requirements of the safe harbor could nevertheless be invalidated because attestation, which provides reliable objective evidence of testamentary intent, ${ }^{177}$ would no longer be required. The elimination of the attestation requirement could therefore have both a positive and a negative effect on the therapeutic consequences of testamentary freedom because, although the testator would have less trouble entering the safe harbor, the safe harbor's protection would be diminished. As a result, the net effect of the elimination of attestation on the therapeutic potential of testamentary freedom is ambiguous.

Although the cumulative effect of this reform on the therapeutic consequences of freedom of testation is unclear, such a reform would lessen the testator's incentive to consult an estate planning attorney and consequently would diminish the lawyer's role as a therapeutic agent. ${ }^{178}$ As previously discussed, the formal requirements of will execution provide the testator an incentive to seek legal advice during the will-execution process. ${ }^{179}$ However, without an attestation requirement, this incentive would be weakened because the overall level of formality would be reduced, and the testator's perceived need for legal assistance consequently would be diminished.

This effect of eliminating the attestation requirement is manifest in statutes that authorize holographic wills. A holographic will is a testamentary document that is handwritten by the testator and is valid without attestation. ${ }^{180}$ The traditionally accepted justification for holographic wills is that the reduced formality enables the testator to prepare a will at home without the aid of an attorney. ${ }^{181}$ Both the drafters of statutes that authorize holographic wills and probate courts that determine their validity have explained that the purpose of this reduced formality is to provide

177. See Langbein, supra note 84, at 494 ("[T]he formalities for witnessed wills call for a virtually unmistakable testamentary act....”). Indeed, when the level of formality is low, cases are "bound to arise in which the court must decide whether the decedent meant the writing to be a will." Id. at 515 .

178. See supra Part III.A.2.

179. See supra Part III.A.3.

180. DUKEMINIER ET AL., supra note 6, at 268; see also Richard Lewis Brown, The Holograph Problem-The Case Against Holographic Wills, 74 TENN. L. REv. 93, 93-94 (2006) ("[S]tatutes that authorize holographic wills create an exception to the nearly universal rule that a valid will must be witnessed.”).

181. See, e.g., Brown, supra note 180, at 127-28; Stephen Clowney, In Their Own Hand: An Analysis of Holographic Wills and Homemade Willmaking, 43 REAL PROP. PROB. \& TR. J. 27, 30 (2008) ("Without hiring a lawyer or involving witnesses, testators in some jurisdictions easily can put pen to paper, secure in the knowledge that the law must honor their final wishes.”). 
those who are unable or unwilling to engage an attorney an opportunity to validly exercise testamentary power. ${ }^{182}$ Therefore, by eliminating the attestation requirement, holographic will statutes encourage the execution of wills without the aid of lawyers. ${ }^{183}$

The elimination of the attestation requirement, which is the defining characteristic of witnessed wills, would eliminate most of the distinction between formally attested wills and holographic wills. Therefore, because "[l]egislative recognition of the holographic form ... encourages testators to draw their own wills," 184 legislative approval of reduced formality for all testamentary documents would gradually decrease the testator's incentive to engage an estate planning attorney. ${ }^{185}$ As a result, the lawyer's role as a therapeutic agent for the testator would be weakened and the therapeutic potential of the will-execution process would be diminished.

In addition to diminishing the therapeutic role of the estate planning attorney, the reduction of testamentary formality through the elimination of the attestation requirement would lessen the therapeutic benefit of the will-execution ceremony. ${ }^{186}$ Formalities are the central elements of the will-execution process and provide the process its ritualistic character by distinguishing the ceremony from the events of everyday life. ${ }^{187}$ If the testator no longer had to fulfill an attestation requirement, the will-

182. See UnIF. Probate CodE § 2-503 cmt. (1969) ("For persons unable to obtain legal assistance, the holographic will may be adequate.”); In re Succession of Bacot, 502 So. 2d 1118, 112122 (La. Ct. App. 1987) ("The principal value of an [h]olographic testament is simplicity. It can be confected by a layman without the assistance of legal counsel.”); In re Estate of Teubert, 298 S.E.2d 456, 460 (W. Va. 1982) ("The purpose behind statutory recognition of holographic wills is to enable those persons who are unable or unwilling to secure the assistance of counsel to make a valid will in their own handwriting.”); see also Kevin R. Natale, Note, A Survey, Analysis, and Evaluation of Holographic Will Statutes, 17 HOFSTRA L. REV. 159, 160 (1988) (“Legislatures authorize holographic wills as a means of convenience to testators, enabling those who are either unable or unwilling to obtain legal assistance to make a valid will in their own handwriting.").

183. See In re Soher's Estate, 21 P. 8, 10 (Cal. 1889) (explaining that "testators are to be encouraged by [holographic will] statute[s] . . . to draw their own wills . ..."); Brown, supra note 180, at 127 (arguing for the abolition of holographic wills to "encourage testators to seek professional guidance in the preparation of their wills"); Natale, supra note 182, at 177 n.98 (explaining that by authorizing holographic wills "legislatures encourage the informal drafting of wills by lay persons with no legal training or professional advice").

184. Gail Boreman Bird, Sleight of Handwriting: The Holographic Will in California, 32 HASTINGS L.J. 605, 631 (1981).

185. See, e.g., Miller, supra note 165, at 630 (stating that holding holographic wills as enforceable creates freedom and flexibility); Note, Holographic Wills in Virginia: Problems at Probate, 45 VA. L. REV. 613, 628 (1959) (stating that a "statute that permits holographs encourages informal drafting").

186. See supra notes $72-75$ and accompanying text.

187. See supra Part III.A.3. 
execution ceremony would lose this unique characteristic and its ritualistic nature would be diminished because the execution of a will would more closely resemble less significant transactions. ${ }^{188}$

Of course, the elimination of the attestation requirement would not negatively affect the ritualistic character of will execution if testators continued to have their wills witnessed. In fact, the proposals to abolish the attestation requirement acknowledge that witnessed wills are desirable, and the proponents of these plans suggest that testators can be encouraged to have their wills witnessed even without mandatory invalidation of unattested documents. ${ }^{189}$ For example, requiring attestation only for self-proving wills or making attestation an aspirational requirement could encourage the continued use of witnesses in the will-execution process. $^{190}$ The effectiveness of these incentives, however, depends largely on estate planning lawyers advising their clients of the administrative advantages of fulfilling a nonobligatory attestation requirement. ${ }^{191}$

Although estate planning attorneys would likely "opt for maximum formality" and continue to have wills witnessed "in order to be in the best possible position to defend... will[s] against” claims of invalidity based upon the absence of testamentary intent, ${ }^{192}$ testators who lack legal assistance would less likely perpetuate attestation's role in the willexecution process. Indeed, statutes that authorize holographic wills acknowledge that testators who attempt to exercise testamentary power without the aid of an attorney are less likely to involve witnesses in the

188. See Langbein, supra note 84, at 508 ("[W]ithout the somber ceremony of attestation, the forms of transfer are closer to those of everyday routine ... .”); Lindgren, supra note 140, at 541 (explaining that " $\mathrm{t}]$ he most characteristic formality of a typical will is the requirement that a will be attested by two (or three) witnesses.” (footnotes omitted)).

189. See Lindgren, supra note 140, at 572 ("We can secure the benefits of the attestation requirement for almost all wills without punishing those few testators who stumble along the way.”); Lindgren, supra note 87, at 1026 (discussing alternatives to mandatory attestation).

190. Lindgren, supra note 140, at 570-71; see also Lindgren, supra note 87, at 1026 (adding that the dispensing power is another method to encourage attestation).

191. In his proposal to abolish the attestation requirement, Professor Lindgren acknowledges the lawyer's role in encouraging the continued observance of attestation. See Lindgren, supra note 140, at 570-72 (explaining that if attestation is required for self-proving wills, estate planning attorneys will perpetuate the attestation requirement because "[l]aw firms do not want to have to track down witnesses years after the execution of a will" and explaining further that, if attestation is made an aspirational requirement, "most people, particularly lawyers, would abide by such a toothless provision.”); Lindgren, supra note 87, at 1026-27 (explaining that “good firms usually get the witnesses' testimony made part of the will" and proposing a method of encouraging attestation by which "supervising a will execution other than one's own without using witnesses could subject the lawyer or other professional to a fine.”).

192. Langbein, supra note 84 , at 524. 
will-execution process. ${ }^{193}$ Because reducing testamentary formality would diminish the testator's incentive to seek legal advice, ${ }^{194}$ the elimination of mandatory attestation could pose a greater threat to its continued adherence than proponents of reform recognize. The ritualistic character of the will-execution ceremony, and its corresponding therapeutic potential, consequently could be diminished by the elimination of the attestation requirement, regardless of whether estate planning lawyers continue to advise their clients of the advantages of witnessed wills.

All in all, the elimination of the attestation requirement would likely have a negative effect on the therapeutic function of testamentary formality. The therapeutic consequences of the protections of the testamentary safe harbor, of the incentive to seek the aid of an estate planning attorney, and of the ritualistic nature of the will-execution ceremony could all be negatively affected by the elimination of the attestation requirement. Therefore, when contemplating amending their state's probate code, policymakers should consider the antitherapeutic consequences that would likely result from eliminating the attestation requirement. Indeed, therapeutic jurisprudence suggests that attestation should continue to be a formal requirement of will execution.

\section{Validation of Notarized Wills}

In addition to the reduction of ancillary formalities and the elimination of the attestation requirement, the authorization of notarized wills is another proposed reform of the law of succession. ${ }^{195}$ This reform is part of the 2008 amendments to the UPC and provides that a will is valid if it is attested by two witnesses or acknowledged by the testator before a notary public. ${ }^{196}$ The testator therefore has an option regarding her preferred method of will execution. Because this reform renders the attestation formality optional, the authorization of notarized wills should be analyzed within the therapeutic jurisprudential framework of estate planning to determine how the reform affects the therapeutic function of testamentary formality.

When examined from a therapeutic jurisprudential perspective, the notarization option for will execution would increase testation's thera-

\footnotetext{
193. See supra notes $187-90$ and accompanying text.

194. See supra notes $180-85$ and accompanying text.

195. See generally Lawrence W. Waggoner, The UPC Authorizes Notarized Wills, 34 ACTEC J. 83 (2008).

196. UnIF. Probate Code § 2-502 (amended 2008), 8 U.L.A. 136 (Supp. 2012).
} 
peutic potential because the reform would weaken the testator's barrier to the exercise of testamentary freedom. In fact, the drafters of the UPC intended that, by providing an alternative method of will execution, this reform would reduce the chances that the testator would execute a formally deficient testamentary document. ${ }^{197}$ As such, this reform could cure a significant number of defective wills, as many people, including some lawyers, believe that notarization is a legitimate alternative to attestation. ${ }^{198}$ By bringing the will-execution process in line with the expectations of a larger segment of the population and by weakening formality's ability to impede the exercise of testamentary freedom, the authorization of notarized wills would bolster the therapeutic qualities of testamentary freedom.

Furthermore, the authorization of notarized wills would not detrimentally affect the other aspects of testamentary formality's therapeutic function. First, when compared with attestation, notarization would provide equally reliable evidence of testamentary intent ${ }^{199}$ and would therefore create an effective testamentary safe harbor. ${ }^{200}$ This consequence of the notarization option would in turn provide the testator the therapeutic benefit of knowing that her testamentary preferences will be fulfilled. ${ }^{201}$ Second, because notarization, like attestation, contributes an aura of formality to the process, the notarization requirement would also maintain the therapeutic benefit of the will-execution ceremony. ${ }^{202}$ Both formalities introduce outsiders into the testamentary experience, a characteristic

197. See Waggoner, supra 195, at 85 ("As long as it is clear that the decedent adopted the document as his or her will, the law has no reason to deny validity on the ground of defective execution. The harmless-error rule is one curative measure for this problem. Allowing notarization as an optional method of execution is another.”).

198. See Unif. PRobate Code § 2-502 cmt., 8 U.L.A. 137 ("[L]ay people (and, sad to say, some lawyers) think that a will is valid if notarized, which is not true under non-UPC law.”); see, e.g., In re Estate of Saueressig, 136 P.3d 201, 202 n.3 (Cal. 2006) (“[T]he only reasonable inference to be drawn from the decedent's conduct is that he believed the notarization would validate his will." (internal quotation marks omitted)).

199. UNIF. Probate Code § 2-502 cmt., 8 U.L.A. 137 (explaining that the execution of a will under the mistaken belief that notarization and not attestation is a requirement for validity provides no "evidence raising any doubt that the will truly represent[s] the decedent's wishes"); In re Estate of Hall, 51 P.3d 1134, 1135-36 (Mont. 2002) (finding that a notarized will provided clear and convincing evidence of testamentary intent); Waggoner, supra note 195, at 84 ("The danger that a notarized will would not reliably represent the decedent's wishes seems minimal.”).

200. See Waggoner, supra note 195, at 84 (explaining that notarization serves the channeling function of testamentary formality).

201. See supra Part III.A.1.

202. See Waggoner, supra note 195, at 84 (explaining that notarization serves the cautionary or ceremonial function of testamentary formality). 
that is integral to the ceremony of will execution. ${ }^{203}$ Notarization would therefore maintain the general ritualistic nature of the will-execution process. ${ }^{204}$ Finally, because the will-execution process for notarized wills would be as technically complex as that for attested wills, it is unlikely that providing the testator a choice between attestation and notarization would weaken the testator's incentive to seek the aid of an estate planning attorney. The authorization of notarized wills consequently would not diminish the estate planning attorney's opportunity to serve as a therapeutic agent for her client.

In sum, the authorization of notarized wills would have a net therapeutic effect on the will-execution process. For instance, the authorization of notarized wills would lessen formality's opportunity to impede the exercise of testamentary freedom. Further, by providing the testator an option to comply with the attestation requirement or the notarization requirement, this reform would also maintain the therapeutic aspects of testamentary formality, including the testamentary safe harbor, the testator's incentive to seek legal assistance, and the ritualistic nature of the will-execution ceremony. Therapeutic jurisprudence therefore suggests that the authorization of notarized wills is an overall therapeutic reform of the law of wills.

\section{B. Relaxed Testamentary Formalism}

In addition to the reduction of testamentary formality, the law reform movement has called for the relaxation of testamentary formalism. Under the traditional rule of strict compliance, any formal defect invalidates a will. ${ }^{205}$ Consequently, strict compliance has produced situations in which testamentary intent is clear, but the will is invalid because the testator failed to comply with one of the required formalities. ${ }^{206}$ To avoid this frustration of testamentary intent, scholars have proposed two alter-

203. See Langbein, supra note 84, at 497.

204. In this regard, notarization may actually increase the ceremonial quality of will execution because whereas attesting witnesses need not have any special qualifications, the notary public is a public official with "the foremost duty ... to screen signers of particularly sensitive instruments ... for their true identity, their willingness to sign without duress or intimidation, and their awareness of the general import of the document." What is a Notary?, NAT'L NOTARY Ass'N, http://www.nationalnotary.org/what_is_notary/index.html (last visited Sept. 7, 2012).

205. See DUKEMINIER ET AL., supra note 6, at 228.

206. See, e.g., Stevens v. Casdorph, 508 S.E.2d 610, 613 (W. Va. 1998) (holding that the "mere intent by a testator to execute a written will is insufficient" because "[t]he actual execution of a written will must also comply with the dictates of" the required formalities); Miller, supra note 116, at 222-23. 
natives to the rule of strict compliance. First, the substantial compliance doctrine recognizes a will as valid if the testator intends to create a will and substantially complies with the required formalities. ${ }^{207}$ Alternatively, the harmless error rule allows the court to validate a will based solely on whether the testator clearly expresses testamentary intent. ${ }^{208}$

These alternatives not only would reduce the potential harshness of strict compliance, but would also affect the therapeutic function of testamentary formality. For example, the relaxation of testamentary formalism would likely increase the therapeutic consequences of the testamentary safe harbor ${ }^{209}$ and decrease the likelihood that testamentary formality will impede the exercise of testamentary freedom. ${ }^{210}$ Similar to the elimination of the attestation requirement, the relaxation of testamentary formalism would reduce the burdens of will execution, thereby reducing the possibility that a court will invalidate a testamentary document because of deficient execution. ${ }^{211}$ Indeed, under both alternatives, a probate court will not automatically invalidate a formally deficient will; instead, the will's proponent will have the burden of proving testamentary intent. ${ }^{212}$ This consequence of relaxed formalism would have positive therapeutic consequences because it would provide the testator greater assurance that a genuine expression of testamentary intent will be recognized as legally valid.

Unlike the reduction of testamentary formality, however, the adoption of the substantial compliance doctrine or the harmless error rule would not produce antitherapeutic consequences by reducing the protections of the safe harbor. Whereas the elimination of the attestation requirement would increase the likelihood that testamentary intent would be disputed, ${ }^{213}$ the relaxation of testamentary formalism would maintain the current level of certainty that documents satisfying the safe harbor's requirements will be recognized as legally valid wills. ${ }^{214}$ The validity of

\footnotetext{
207. Langbein, supra note 84 , at 489.

208. See Langbein, supra note 87, at 5-7.

209. See supra Part III.A.1.

210. See supra Part III.B.

211. See Langbein, supra note 84, at 489 (explaining the rationale of the substantial compliance doctrine: "The finding of a formal defect should lead not to automatic invalidity, but to a further inquiry: does the noncomplying document express the decedent's testamentary intent, and does its form sufficiently approximate Wills Act formality to enable the court to conclude that it serves the purposes of the Wills Act?”).

212. Id.

213. See supra notes $176-78$ and accompanying text.

214. See Langbein, supra note 84, at 525 ("The substantial compliance doctrine would pertain not to every will, but to that fraction of wills where the testator ... has failed to comply fully with
} 
some documents that appear testamentary in nature may still be questioned, ${ }^{215}$ but most testators who leave behind written, signed, and attested wills would be assured that their testamentary preferences will be honored. ${ }^{216}$

In sum, a rule of relaxed testamentary formalism "makes the[] formalities for execution a mere safe harbor," as "those who seek absolute certainty may comply with such formalities and are assured that the law will recognize their wills as validly executed"; however, those who fail to strictly comply are not foreclosed from exercising testamentary power through the execution of a will. ${ }^{217}$ The relaxed formalism of the substantial compliance doctrine and the harmless error rule therefore likely would have therapeutic consequences because the testator can be certain that her testamentary preferences will be honored if she complies with the prescribed formalities, but she need not worry that a minor defect in execution will automatically invalidate the will.

The adoption of the substantial compliance doctrine or the harmless error rule, however, could reduce the estate planning attorney's role as a therapeutic agent for her client ${ }^{218}$ and diminish the ritualistic nature of the will-execution ceremony. ${ }^{219}$ Much like the effect of eliminating the attestation requirement, ${ }^{220}$ a rule of relaxed testamentary formalism could encourage testators to execute wills informally and without the assistance of a lawyer. Because a formal defect would no longer automatically invalidate an attempted expression of testamentary intent, the harsh consequences of forgoing legal assistance would be reduced and consequently the testator's incentive to consult an estate planning attorney would be diminished. $^{221}$ The relaxation of testamentary formalism could also en-

the Wills Act formalities.”); Langbein, supra note 87, at 52 (explaining that the harmless error rule "has left unaffected the estates of testators who have complied fully with the Wills Act formalities.”).

215. See Langbein \& Waggoner, supra note 92, at 541-42 (discussing "the so-called 'sham will' cases").

216. See Miller, supra note 116, at 274-75 (stating that a signed will "produces a powerful inference of validity by creating a presumption that the recitals in the signature and attestation clauses are true.").

217. E. Gary Spitko, The Expressive Function of Succession Law and the Merits of Non-Marital Inclusion, 41 ARIZ. L. REV. 1063, 1085 (1999).

218. See supra Part III.A.2.

219. See supra Part III.A.3.

220. See supra notes 186-95 and accompanying text.

221. See supra Part III.A.2 (discussing the incentive that legal formalities provide for the testator to engage an estate planning attorney). But see Langbein, supra note 84, at 524 (arguing that relaxed testamentary formalism "would not attract the reliance of amateurs, nor increase the number 
courage the testator to abandon strict adherence to the formalities of will execution because simpler and cheaper methods of executing a will would be legally valid. ${ }^{222}$ Consequently, such a reform could diminish the therapeutic qualities of the will-execution ceremony.

Moreover, regardless of whether testators and estate planning lawyers would continue to observe will formalities despite a rule of relaxed formalism, both the substantial compliance doctrine and the harmless error rule could diminish the ritual of will execution because the formalism that mandates invariable compliance with the formalities of will execution is a fundamental aspect of the ceremony's ritualistic character. ${ }^{223}$ Simply by rendering compliance with formality discretionary, a rule of relaxed formalism would diminish this ritualistic trait, even if testators continued to strictly comply. Tacitly recognizing this erosion of will execution's ritualism, those who argue that testators would continue to strictly comply despite the relaxation of testamentary formalism concede that "[a]t a minimum, the mystique surrounding wills, which leads most lay people to believe that a will is a solemn transaction in which they should seek legal assistance, could eventually disappear."224

Despite this antitherapeutic potential, a reduction in the average testator's compliance with will formalities would likely be small and gradual because the testator would retain a strong incentive to strictly comply. ${ }^{225}$ For example, if executed informally, a will would not qualify for the protections of the testamentary safe harbor, and the issue of testamen-

of homemade wills.”).

222. See Hirsch, supra note 95, at 1067 n.33 (explaining that "[t]he ex ante consequence of [relaxed formalism] could be greater laxity in fulfilling formal requirements ....”); Miller, supra note 165 , at 707 ("A potential objection to a harmless error rule . . . is that permitting the courts to validate defective wills may eventually undercut the standard set by the wills act.”); Emily Sherwin, Clear and Convincing Evidence of Testamentary Intent: The Search for a Compromise Between Formality and Adjudicative Justice, 34 ConN. L. REv. 453, 468 (2002) ("If it is generally understood that judges have the power to dispense with formality requirements . . . testators might come to believe that the statutory procedures are no longer necessary. Accordingly, they might gradually abandon traditional testamentary procedures in favor of other, perhaps cheaper, means of expressing testamentary intent.”). But see Langbein, supra note 84, at 524 (arguing that relaxed testamentary formalism "would have no effect whatever upon primary conduct.”).

223. See supra notes $106-14$ and accompanying text.

224. Sherwin, supra note 222, at 469.

225. See id. ("[T] $]$ he premise of the argument, that a dispensation rule will lead to lax testamentary practices, may be incorrect. A testator sufficiently informed to know of the will statutes has powerful reason to follow them, whether or not courts have authority to accept defective wills."); see also J.G. Miller, Substantial Compliance and the Execution of Wills, 36 INT’L \& COMP. L.Q. 559, 577 (1987) (arguing that relaxed formalism will not "breed some contempt for the prescribed formalities" because "human instinct is more likely to lead to a desire to do things properly ...."). 
tary intent would more likely be litigated. ${ }^{226}$ The testator consequently would have an incentive to comply with the prescribed formalities to qualify for the protections of the testamentary safe harbor and avoid the expense and inconvenience of probate litigation. ${ }^{227}$ Because informal will execution is "hardly an enticing option," 228 the decrease in the testator's incentive to comply with the prescribed formalities and engage an estate planning attorney therefore would likely be minimal. In fact, this intuition is confirmed by the experience of foreign jurisdictions that have abandoned strict formal compliance without discernibly increasing the use of informal methods of will execution in the decades following the abandonment of the rule. ${ }^{229}$

In sum, by abandoning strict compliance, the relaxation of testamentary formalism could potentially weaken the testator's incentive to strictly comply with the prescribed formalities and to seek the aid of an estate planning attorney. Consequently, to some minimal extent, the adoption of the substantial compliance doctrine or the harmless error rule could diminish the therapeutic consequences of the will-execution ceremony and decrease the estate planning attorney's role as therapeutic agent. However, the threat of these antitherapeutic effects is minor, because a rule of relaxed testamentary formalism maintains the protections of the testamentary safe harbor, and the experience of other jurisdictions suggests that such a reform only minimally, if at all, diminishes the testator's incentive to seek legal advice and strictly comply. Because they assist the testator in avoiding potentially burdensome estate litigation over testamentary intent, will formalities are "naturally resilient,"230 and would likely continue to provide the testator a robust incentive to avoid informal methods of will execution, even if a rule of relaxed formalism were adopted. Therefore, the positive psychological consequences of removing the impediment of strict testamentary formalism from the testator's exercise of testamentary freedom likely outweigh any potential antither-

226. See Spitko, supra note 217, at 1085-86.

227. See Langbein, supra note 84, at 524 ("The incentive for due execution would remain. Precisely because the substantial compliance doctrine is a rule of litigation, it would have no place in professional estate planning.”).

228. Langbein, supra note 87, at 23; see Langbein, supra note 84, at 524.

229. See Langbein, supra note 87, at 51-52 (concluding after a review of the experience of a variety of foreign jurisdictions that a rule of relaxed formalism has not "inspired testators to become sloppy about executing their wills ....”); Miller, supra note 116, at 319 (explaining that south Australia's rule of relaxed formalism has not affected the attitude toward formalities).

230. Sherwin, supra note 222, at 475 (explaining further that "will formalities are unlike typical rules of conduct, which actors may have strong reasons to disregard if courts treat the rules as advisory rather than mandatory.”). 
apeutic effects of abandoning the rule of strict compliance.

All told, because relaxed testamentary formalism would affect testamentary formality's therapeutic function, therapeutic consequences are relevant considerations when evaluating proposals to adopt the substantial compliance doctrine or the harmless error rule. When employed in this context, therapeutic jurisprudence ultimately suggests that the reformation of the law of wills to include a relaxed compliance rule would likely produce a net therapeutic result. Thus, therapeutic jurisprudence adds to the resounding call for reform with respect to strict testamentary formalism and suggests that state legislatures should amend their probate codes to include a rule of relaxed formal compliance. A therapeutic jurisprudential analysis therefore not only recognizes testamentary formality's therapeutic function, but also provides the law reform movement new insights regarding strict testamentary formalism that strengthen the case for reform.

\section{CONCLUSION}

A therapeutic jurisprudential analysis reveals that testamentary formality serves a therapeutic function. ${ }^{231}$ As part of the larger context of preparing and implementing an estate plan, will formalities fulfill their therapeutic function by interacting with the therapeutic and antitherapeutic qualities of the estate planning process. This process has a number of positive and negative psychological consequences, all of which affect the psychological well-being of the testator. ${ }^{232}$ This Article argues that testamentary formality enhances the overall therapeutic potential of the estate planning process by bolstering the positive psychological consequences of preparing an estate plan and diminishing the process's antitherapeutic qualities.

The recognition of testamentary formality's therapeutic function represents the first step of a therapeutic jurisprudential analysis. ${ }^{233}$ The second step of the process entails employing the therapeutic and antitherapeutic consequences of the law as a framework through which to analyze potential law reforms and identify ways to maximize the law's overall therapeutic potential. ${ }^{234}$ Given this goal, therapeutic jurisprudence reveals the need to analyze how the various proposed reforms of the will-

\footnotetext{
231. See supra Part III.

232. See Glover, supra note 1, at 433-61.

233. See supra Part II.A.

234. See supra Part II.A.
} 
execution process would affect testamentary formality's therapeutic function.

The law reform movement in the law of wills has proposed two general types of reforms, both of which lessen formality's role in the estate planning process and therefore threaten to undermine formality's therapeutic function. These reforms consist of the reduction of testamentary formality ${ }^{235}$ and the relaxation of testamentary formalism. ${ }^{236}$ The reduction of testamentary formality entails eliminating or replacing some of the traditionally required formal elements of will execution, including reducing ancillary testamentary formality, eliminating the attestation requirement, and authorizing notarized wills. By contrast, the relaxation of testamentary formalism involves replacing the rule of strict compliance, which has long required strict literal compliance with the prescribed formalities, with a more lenient formal compliance standard. ${ }^{237}$ Therapeutic jurisprudence suggests that all of these reforms, except for the elimination of the attestation requirement, would produce cumulative therapeutic results.

Most importantly, however, a therapeutic jurisprudential analysis adds to the arguments in support of the relaxation of strict testamentary formalism. The law reform movement has called for reform in this area for over thirty-five years with little success. ${ }^{238}$ However, therapeutic jurisprudence confirms the prudence of this reform and provides new momentum to the law reform movement that urges the adoption of a relaxed compliance standard. All in all, therapeutic jurisprudence provides a new, insightful perspective of the role of testamentary formality in the estate planning process and ultimately suggests that therapeutic consequences are relevant considerations for the reformers of the law of succession. By considering these consequences, reformers can maximize the therapeutic potential of the law and maintain the therapeutic function of testamentary formality.

\footnotetext{
235. See supra Part IV.A.

236. See supra Part IV.B.

237. See supra Part IV.B.

238. This law reform movement began with Professor John Langbein's proposal, in 1975, for the adoption of the substantial compliance doctrine. See generally Langbein, supra note 84 . Since that time only a handful of states have adopted the harmless error rule, which is the successor to Langbein's substantial compliance doctrine. See Waggoner, supra note 195, at 83.
} 